\title{
On some features of low-temperature mixed crystallization of CsI solutions obtained from industrial wastes
}

\author{
A.Yu.Boyarintsev ${ }^{1}$, V.L.Cherginets ${ }^{1}$, T.V.Ponomarenko $^{1}$, \\ T.P.Rebrova ${ }^{1}$, A.G.Varich ${ }^{1}$, E.Yu.Bryleva ${ }^{2,3}$, E.M.Koryakina ${ }^{2}$, \\ T.V.Sheina ${ }^{2}$, V.V.Varchenko ${ }^{2}$, O.I.Yurchenko ${ }^{3}$ \\ ${ }^{1}$ Institute for Scintillation Materials, STC ""Institute for Single Crystals" \\ National Academy of Sciences of Ukraine, 60 Nauky Ave., 61001 Kharkiv, \\ Ukraine \\ ${ }^{2}$ STC "Institute for Single Crystals", National Academy of Sciences of \\ Ukraine, 60 Nauky Ave., 61001 Kharkiv, Ukraine \\ ${ }^{3}$ V.N.Karazin Kharkiv National University, 4 Svobody Sq., 61022 \\ Kharkov, Ukraine
}

Received May 22, 2017

Investigation of multiple low-temperature mixed crystallization (LTMC) of the solution wastes of cesium iodide was reported. LTMC is a very simple and convenient way for an essential decrease of the concentrations of practically all the admixtures including isomorphic ones ( $\mathrm{Na}, \mathrm{K}, \mathrm{Rb})$. However, LTMC results in Csl enriching with TI, which enters into the crystallized fraction. Due to the presence of considerable amounts of $\mathrm{Na}$ and sulfate admixtures during the first 3-4 LTMC the displacement of other admixtures occurs with lower intensity comparing with the following LTMC stages and the threshold concentration of $\mathrm{Na}$ is ca. $5 \cdot 10^{-2}$ wt.\%. For $\mathrm{Na}$ the effective purification coefficient $\beta$ is $0.6-0.7$ for the initial solution and it reduces to $0.35-0.5$ in more pure solutions, for $\mathrm{K}$ these values are 0.75 and $0.5-0.55$. Na content does not affect $\mathrm{Rb}$ distribution and for this admixture $\beta \approx 0.65-0.75$ for all the solutions. For $\mathrm{Cu}$ the value of $\beta$ is close to 1 since $\mathrm{Cul}$ is insoluble in water and LTMC favors its entering in the solid fraction. $\beta$ value for $\mathrm{TI}$ admixture is ca. 1.06 that means the enriching of the final product of LTMC with respect to this admixture. The removal of sulfates from Csl using LTMC occurs very easy.

Keywords: cesium iodide, wastes, low-temperature mixed crystallization, effective purification coefficient.

Проведено изучение многократной низкотемпературной смешанной кристаллизации (HCК) техногенных растворов йодида цезия. Этот метод является простым и удобным для существенного снижения концентрации практически всех примесей, в том числе изоморфных $(\mathrm{Na}, \mathrm{K}, \mathrm{Rb})$. Однако в процессе кристаллизации продукт обогащается примесью таллия, который преимущественно входит в закристаллизовавшуюся часть. Вследствие значительного загрязнения техногенных отходов примесями натрия и сульфатов в течение первых 3-4 НСК процесс вытеснения других примесей происходит менее интенсивно,чем впоследствии, пороговая концентрация ионов натрия $-5 \cdot 10^{-2}$ wt. \% . Для натрия эффективный коэффициент очистки $\beta$ находится в пределах 0,6-0,7 для исходного раствора и по мере очистки уменьшается до $0,35-0,5$, для калия соответствующие значения 0,75 и $0,5-0,55$, для рубидия $-\beta=0,65-0,75$ и не зависит от содержания натрия. Для меди әффективный коэффициент очистки близок к единице вследствие того, что Cul нераство- 
рим в воде и при кристаллизации преимущественно входит в закристаллизовавшуюся часть. Для таллия әффективный коэффициент очистки несколько больше единицы, что указывает на последовательное накопления этой примеси в продукте при НСК. Сульфат-ионы достаточно легко вытесняются в процессе НСК отходов производства монокристаллов йодида цезия.

Особливості низькотемпературної мішаної кристалізації розчинів йодиду цезію, одержаних з промислових відходів. А.Ю.Бояринщев, В.Л.Чергинець, Т.В.Поноларенко, Т.П.Реброва, А.Г.Варич, К.Ю.Брильова, О.М.Карякіна, Т.В.Шеїна, В.В.Варченко, О.І.Юр ченко.

Багаторазова низькотемпературна мішана кристалізація (НMК) техногенних розчинів йодиду цезію є простим і зручним методом для суттєвого зниження концентрації практично усіх домішок, у тому числі ізоморфних (Na, K, Rb). Однак у процесі кристалізації продукт збагачується домішкою талію, який переважно входить у закристалізовану частину. Внаслідок значного забруднення техногенних відходів домішками натрію і сульфатів протягом перших 3-4 НМК процес витіснення інших домішок відбувається менш інтенсивно, ніж надалі, порогова концентрації іонів натрію $-5 \cdot 10^{-}$

2 мас.\%. Для натрію ефективний коефіцієнт очищення, $\beta$, знаходиться у межах $0,6-$ 0,7 для вихідного розчину $\mathrm{i}$ в міру очищення зменшується до $0,35-0,5$, для калію відповідні значення 0,75 і 0,5-0,55, для рубідію $\beta=0,65-0,75$ і не залежить від вмісту натрію. Для купруму ефективний коефіцієнт очищення близький до одиниці внаслідок того, що Cul $\epsilon$ нерозчинним у воді і при кристалізації переважно входить у закристалізовану частину. Для талію ефективний коефіцієнт очистки є трохи більшим від одиниці, що вказує на поступове накопичення цієї домішки у продукті при НМК. Сульфат-іони досить легко витісняються у процесі НМК відходів виробництва монокристалів йодиду цезію.

\section{Introduction}

Single crystals based on alkali metal iodides (mainly, CsI and Nal) are widely used for the creation of working parts of optical equipment of different applications. In particular, CsI crystals are applied for making windows transparent in IR range due to their low hygroscopicity and the absence of absorption bands in the said part of spectrum [1]. The main part of the iodide single crystals (Csl, Csl:Na, Csl:Tl, Nal:Tl) is scintillation detectors applied for different purposes (medical tomography, high-energy physics, cosmic and nuclear instrument engineering, the logging of drill holes etc.) as detectors of the ionizing radiation of various origin [2]. Annual production volume of the scintillation single crystals is several dozens of tons.

The said single crystals are grown, mainly, by Chokhralski or Kyropoulos methods that permits to grow crystals with masses of several hundred kilos within short interval of time. For the practical applications the grown cylindrical crystals are cut to smaller parts of various geometry. Besides, some pieces with inclusions, cracks, turbidities and other visual defects are removed. Thus, an appreciable part of the grown crystal passes into wastes: nonused solidified melt and deposit from the walls of the growth apparatus, rest pieces (cuttings) which are dissolved in water for the waste unification. These wastes are a serious problem for crystal manufactures and this problem requires urgent solution. The best solution of the waste problem is the returning of the valuable constituents of these wastes (iodine, cesium and thallium) in the production. The separation of thallium does not present a serious problem since TII is practically insoluble in water and slightly soluble in iodide solutions. In the latter case the dependence of the solubility against alkaline metal iodide concentration passes through the minimum corresponding to mass fraction of iodide in the solution within 10-15 wt. \%. The following treatment of $\mathrm{Nal}$ wastes is very simple since the solution after Tll separation contains only one valuable components - iodine. So, the waste solution is acidified and hydrogen peroxide is added to complete precipitation of $\mathrm{I}_{2}$ which is separated from solution by filtration and further it is purified by sublimation.

The processing of Csl wastes is more complicate since they also contain cesium besides iodine. Due to this reason the solution after TIl separation is treated by $\mathrm{Ba}(\mathrm{OH})_{2}$ to precipitate sulfates (as $\mathrm{BaSO}_{4}$ ) and heavy metals, aluminum and magnesium (insoluble hydroxides). Further this solution is treated by $\mathrm{Cs}_{2} \mathrm{CO}_{3}$ to precipitate the excess of barium, alkaline earth metals (as carbonates). Nevertheless, such a way of 
purification does not provide the separation of alkali metal cations (residual content of sodium is varied from 0.1 to 1 wt. \%). The removal of alkali metal cations is the hardest problem, which is solved by multiple recrystallization from aqueous solutions. The above-described method possesses essential disadvantage caused by relatively small changes of Csl solubility with the temperature: from $80 \mathrm{~g} / 100 \mathrm{~g}$ of water at $20^{\circ} \mathrm{C}$ to $200 \mathrm{~g} / 100 \mathrm{~g}$ of water at $100^{\circ} \mathrm{C}[3,4]$. It is obvious that one cycle of recrystallization leads to the loss of approximately $40 \%$ of Csl in the mother waters and the direct yield of Csl after $3^{\text {rd }}$ recrystallization is ca. $25 \%$. The treatment of the mother waters is difficult since the concentration of admixtures in them is considerably higher than in the initial solution. This forces engineers to consider alternative approaches of crystallization or chemical treatment of the waste solutions, which can result in higher yield of extra pure Csl free from $\mathrm{Na}, \mathrm{K}$ and $\mathrm{Rb}$.

Studies of the low-temperature direct crystallization (LTDC) of water-salt eutectic mixtures (WSE) are originated from analytical methods of determination of admixture concentration in the cases where their content is lower than the detection limit. Thorough consideration of the LTDC was performed in the monograph by A.B.Blank [5] where the distribution coefficient for main admixtures at $\mathrm{Csl}-\mathrm{H}_{2} \mathrm{O}$ WSE crystallization were presented. The problem of deep purification of Csl using LTDC was solved in [6]. For this purpose authors took extra pure Csl with the total concentration of admixtures ca. $10^{-3}$ wt. $\%$. The purification resulted in the decreasing of the concentrations of heavy and transition metals to level lower than $10^{-5}-10^{-6}$ wt. \% . Concentrations of alkali metals also reduced although the corresponding quantitative data were absent.

So, there are certain preconditions for the use of LTDC for the purification of technogenic solutions of cesium iodide, although the above-mentioned results cannot be used immediately since the level of admixtures in the salts used in $[5,6]$ was lower by 2 orders of magnitude than usual level of the wastes contamination. Ditto, the complicated equipment was used there for LTDC:tank with antifreeze (for cooling to $-17^{\circ} \mathrm{C}$ ), system for antifreeze stirring, system for rotation of vessel $(10 \mathrm{l})$ with the water-salt eutectic. Considerable volumes of WSE favored the slowing of the crystallization process due to the slight thermal conductivity if the solid WSE. This forces the searching for a new design of LTDC under industrial conditions.

One of ways of developing this routine can be deduced from the fact that usual industrial mass crystallization finishes at room temperature ( $r t)$ and the remaining mother waters contain about of $40 \mathrm{wt}$. \% of Csl whereas the corresponding concentration of Csl in WSE is only $27.5 \mathrm{wt} . \%$. It is of interest to study the process of cooling the solution saturated at $r t$ to crystallize some additional amount of Csl and, then, at $-5.6{ }^{\circ} \mathrm{C}$ WSE. However, such investigations were not performed before. Since in this process crystallization of WSE follows usual mass crystallization (cooling from $r t$ to WSE point) we called this crystallization routine low-temperatire mixed crystallization, LTMC. Its features are discussed below.

\section{Experimental}

Preparation of Csl solution. The technogenic Csl solution was thermostated and its density was measured $\left(\rho=1.10 \mathrm{~g} \cdot \mathrm{cm}^{-3}\right)$. This density corresponds to $\mathrm{Csl}$ concentration ca. 12 wt. \% assuming that admixture amount in the solution can not appreciably affect its density. Then the solution was evaporated to Csl concentration near 3840 wt. \% that was controlled by the loss of the solution wt. Then the cooled solution was separated from the deposit of carbonates $\left(\mathrm{CaCO}_{3}, \mathrm{MgCO}_{3}\right)$ and calcium sulfate and further it was used for LTMC.

$L T M C$. The process was performed in usual freezing chamber cooled to $-12{ }^{\circ} \mathrm{C}$. 1.5 1 PET bottles from mineral or potable water were used as containers. The crystallization degree was $0.96-0.97$ and the time required for LTMC was ca. $36 \mathrm{~h}$. After each LTMC cycle ca. $50 \mathrm{ml}$ of residual solution was removed, the frozen WSE was heated to the formation of homogeneous solution which was subjected to following LTMC (up to 10 cycles). After each LTMC samples of the product and mother waters were evaporated, dried and analyzed.

It should be noted that the first 3 cycles of LTMC occurred without ordered crystallization from vessel walls inside that could be caused by spontaneous formation of crystallization centers into whole bulk caused by the admixtures. Beginning with $4^{\text {th }}$ LTMC there was the directed movement of the crystallization front into the vessel and time necessary for the crystallization somewhat reduced. 
Table 1. Concentrations of certain admixtures (in wt. \%) in cesium iodide purified using multiple LTMC, $g=0.96-0.97$

\begin{tabular}{|c|c|c|c|c|c|c||}
\hline \multirow{2}{*}{$\begin{array}{c}\text { LTMC } \\
\text { No }\end{array}$} & \multicolumn{5}{|c|}{ Concentration, wt. $\%$} \\
\cline { 2 - 7 } & $\mathrm{Na}^{+}$ & $\mathrm{K}^{+}$ & $\mathrm{Rb}^{+}$ & $\mathrm{Cu}^{+}$ & $\mathrm{TI}^{+}$ & $\mathrm{SO}_{4}{ }^{2-}$ \\
\hline Initial & 0.29 & 0.0058 & 0.00013 & 0.000015 & 0.00020 & $>0.01$ \\
solution & & & & & \\
1 & 0.21 & 0.0045 & 0.0001 & 0.000057 & 0.000068 & $>0.01$ \\
2 & 0.13 & 0.0035 & 0.00008 & 0.000026 & 0.000065 & $>0.01$ \\
3 & 0.095 & 0.0019 & 0.00006 & 0.00002 & 0.000068 & $>0.01$ \\
4 & 0.053 & 0.00098 & 0.00004 & 0.000017 & 0.000083 & 0.008 \\
5 & 0.028 & 0.0005 & 0.00002 & 0.000011 & 0.000087 & 0.002 \\
6 & 0.011 & 0.00028 & 0.00002 & 0.000017 & 0.000084 & 0.001 \\
7 & 0.0056 & 0.00018 & $<0.00002$ & 0.000019 & 0.000083 & $<0.0005$ \\
8 & 0.002 & 0.00015 & $<0.00002$ & 0.000017 & 0.00011 & $<0.0005$ \\
9 & 0.0014 & 0.00008 & $<0.00002$ & 0.000016 & 0.00010 & $<0.0005$ \\
10 & 0.00044 & 0.00005 & $<0.00002$ & 0.000008 & 0.00011 & $<0.0005$ \\
\hline \hline
\end{tabular}

Table 2. Concentrations of certain admixtures (in wt. \%) in cesium iodide from mother waters after multiple LTMC, $g=0.96-0.97$

\begin{tabular}{||c|c|c|c|c|c|c||}
\hline \multirow{2}{*}{$\begin{array}{c}\text { LTMC } \\
\text { No }\end{array}$} & \multicolumn{7}{|c|}{ Concentration, wt. \% } \\
\cline { 2 - 7 } & $\mathrm{Na}^{+}$ & $\mathrm{K}^{+}$ & $\mathrm{Rb}^{+}$ & $\mathrm{Cu}^{+}$ & $\mathrm{TI}^{+}$ & $\mathrm{SO}_{4}{ }^{2-}$ \\
\hline $\begin{array}{c}\text { Initial } \\
\text { solution }\end{array}$ & 0.29 & 0.0058 & 0.00013 & 0.000015 & 0.000015 & 0.29 \\
1 & 0.62 & 0.027 & 0.0007 & 0.00018 & 0.000015 & 0.62 \\
2 & 0.87 & 0.037 & 0.0012 & 0.00021 & 0.000015 & 0.87 \\
3 & 0.43 & 0.02 & 0.0005 & 0.00014 & 0.000015 & 0.43 \\
4 & 0.44 & 0.02 & 0.00055 & 0.00015 & 0.000015 & 0.44 \\
5 & 0.21 & 0.01 & 0.0003 & 0.000082 & 0.000015 & 0.21 \\
6 & 0.12 & 0.0056 & 0.00015 & 0.000057 & 0.000015 & 0.12 \\
7 & 0.09 & 0.003 & 0.00009 & 0.000039 & 0.000015 & 0.09 \\
8 & 0.075 & 0.0014 & 0.00005 & 0.000023 & 0.000015 & 0.075 \\
9 & 0.025 & 0.00045 & 0.00003 & 0.000008 & 0.000015 & 0.025 \\
10 & 0.0009 & 0.00033 & 0.00002 & 0.000011 & 0.000015 & 0.0009 \\
\hline \hline
\end{tabular}

Determination of thallium and copper in Csl was performed by differential pulse anodic stripping voltammetry after processing of samples with concentrated nitric acid. Voltammetric measurements were carried out at a hanging mercury drop electrode as a working electrode using 797 VA Computrace (Metrohm, Switzerland). An acetic buffer solution with EDTA ( $\mathrm{pH}$ 5.5) was chosen as a supporting electrolyte. Peaks of thallium and copper were observed at $-0.45 \mathrm{~V}$ and $-0.23 \mathrm{~V}$ (versus $\mathrm{Ag} / \mathrm{AgCl}(3 \mathrm{M} \mathrm{KCl})$ ), respectively. Flame spectrometry was used for $\mathrm{Na}$, $\mathrm{K}$, and $\mathrm{Rb}$ determination. Measurements were carried out using iCE 3500 atomic absorption spectrophotometer (Thermo Fisher) in an emission mode. Flame of acetylene-air gaseous mixture was used as an excitation source. The low determination limit for $\mathrm{Na}$ and $\mathrm{K}$ is $2 \cdot 10^{-5}$ and for $\mathrm{Rb}-5 \cdot 10^{-6}$ wt. $\%$. Relative standard deviation values for concentration interval of $2 \cdot 10^{-5}$ to $2 \cdot 10^{-1} \mathrm{wt}$. $\%$ are within the range of $0.01-0.15$.

Reaction of barium sulfate formation was used for turbidimetric determination of sulfates. Solvent composition (water, $10 \%$ ascorbic acid solution, precipitating agent: $5 \%$ barium chloride solution, diethylene 
glycol, ethanol (1:3:3 by volume)) and temperature regimen provide obtaining a stable suspension of desired dispersity. The low determination limit is $5 \cdot 10^{-4}$ wt. \%. Determination error was not greater than $9 \%$.

\section{Results and discussion}

We considered the obtained results from the viewpoint of chemical engineering meaning that multiple LTMC is the cascade consisting of several separation elements (se). For the separation element " $i$ " we have the following situation. The product from " $i-1$ " stage with admixture concentration of $y_{i-1}$ entered in $s e_{i}$ and the product from " $i$ " stage with admixture concentration of $y_{i}$ (lower than $y_{i-1}$ ) and mother waters with admixture concentration of $x_{i}$ (higher than $y_{i-1}$ ) leave the $s e_{i}$.

The operation efficiency of $s e$ is characterized by the purification coefficients. The thermodynamical purification coefficient $\alpha$ is calculated as:

$$
\alpha=y_{i} / x_{i},
$$

whereas the effective purification coefficient $\beta$ is estimated as follows

$$
\beta=y_{i} / y_{i-1} \text {. }
$$

The initial data used for the analysis of the purification efficiency are presented in Tables 1 (product) and 2 (mother waters), here the crystallization degree was in $g=$ $0.96-0.97$ range.

On the distribution of alkali metal admixtures at LTMC.

The difficulties arising at the purification of cesium iodide from alkali metal cations are caused by the fact that $\mathrm{Na}^{+}, \mathrm{K}^{+}$and $\mathrm{Rb}^{+}$are isomorphic to $\mathrm{Cs}^{+}$.

$\mathrm{Na}^{+}$admixture is referred to the most abundant (from Csl:Na and Cs: $\mathrm{Tl}$ which is doped also by $\mathrm{Na}^{+}$) and harmful contaminations (it makes the salt hygroscopic). The dependences of $\mathrm{Na}^{+}$concentration in the crystallization product and mother waters and purification coefficients are presented in Fig. 1. The obtained dependences (at least, 1-3) can be conditionally split in two sections one of which corresponds to strongly polluted solutions $\left(\mathrm{Na}^{+}\right.$concentration exceeds 0.1 wt. \%) and other is referred to relatively pure ones. As is seen, at cycles 1-3 sodium concentration in the solution remains practically unchanged that demonstrates the features of strongly polluted CsI solutions comparing with the lit-

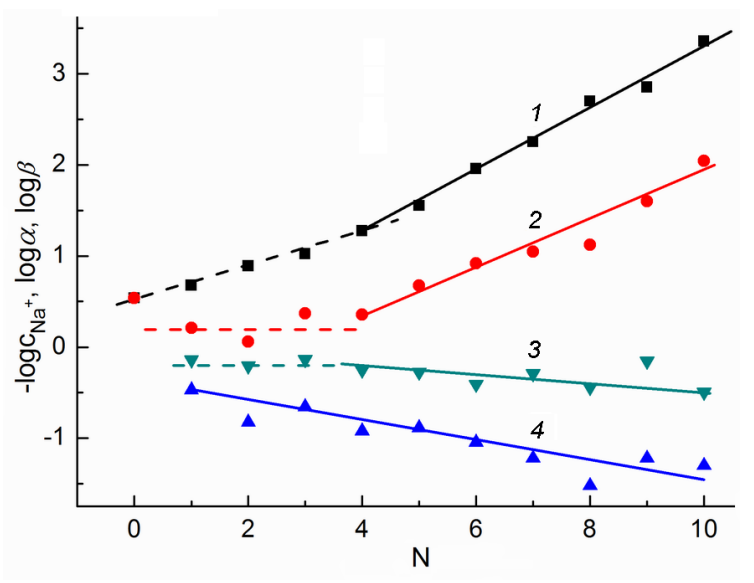

Fig. 1. The dependence of logarithm of $\mathrm{Na}$ concentration $\left(-\log c_{\mathrm{Na}}\right)$ in product (1), mother waters (2) and logarithms of thermodynamic $(\alpha)$ and effective $(\beta)$ purification coefficients on numbers of LTMC cycles $(N)$.

erature data for LTMC of solutions of extra pure Csl. The low efficiency of the purification can be caused by the fact that concentration of sulfate ions in the initial solution are also high and $\mathrm{Na}_{2} \mathrm{SO}_{4}$ is able to form cryohydrate $(T=272 \mathrm{~K}$, concentration of $\mathrm{Na}_{2} \mathrm{SO}_{4}$ is $\sim 4$ wt. \%, phases are $\mathrm{Na}_{2} \mathrm{SO}_{4} \cdot 10 \mathrm{H}_{2} \mathrm{O}$ and ice [7]).

As for the dependences of concentrations, they can be approximated by such lines:

$$
-\log c_{\mathrm{Na}}=a+N(-\log \beta)
$$

where $a$ the free term. The initial section of the dependence $1(N \leq 3)$ is approximated as follows:

$$
-\log c( \pm 0.02)+0.167( \pm 0.01) \cdot N, \beta=0.68 \text {. }
$$

Thus, the process of displacement of sodium into mother waters is more difficult at high admixture concentrations. However, the purification becomes more effective after the $3^{\text {rd }}$ cycle and the corresponding dependence is as follows:

$$
-\log c_{\mathrm{Na}}=-0.04( \pm 0.07)+0.332( \pm 0.01) \cdot N
$$

here $\beta=0.465$. As for $\alpha$ values, for initial cycles they exceed value of 0.1 obtained by Blank [5] and for conditionally pure solutions it agrees with the literature parameter. So, considerable contamination of cesium iodide wastes with sodium essentially complicates the purification process and it requires 3-4 additional LTMC cycles. 


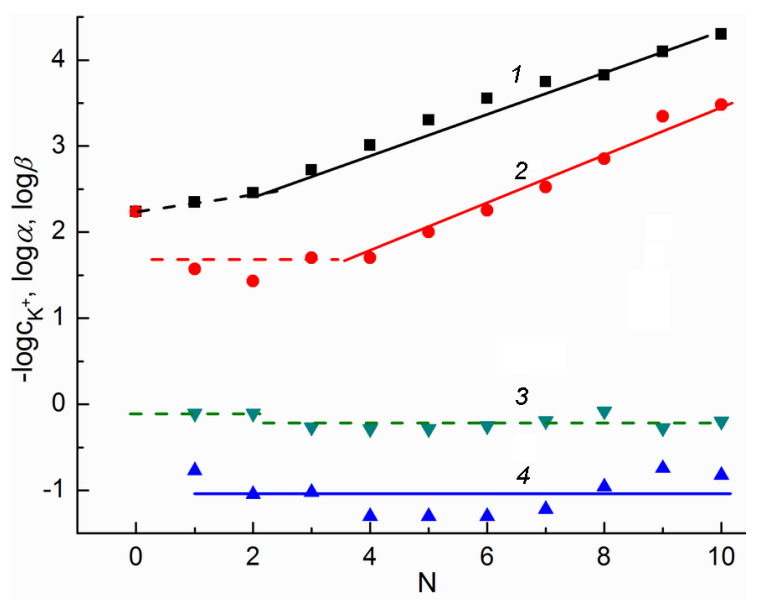

Fig. 2. The dependences of logarithm of $K$ concentration $\left(-\log c_{K}\right)$ in product $(1)$, mother waters (2) and logarithms of thermodynamic $(\alpha)$ and effective $(\beta)$ purification coefficients on numbers of LTMC cycles $(N)$.

Let us consider results concerning potassium distribution at LTMC of the liquid wastes of Csl. This admixture is especially undesirable in $\mathrm{Csl}$ since natural potassium contains ${ }^{40} \mathrm{~K}$ isotope $\left(0.0117 \%, \beta-, \tau_{1 / 2}=\right.$ $1.18 \cdot 10^{9}$ years [8]) causing appreciable intrinsic radiation background in the scintillators. The imagination about the behavior of $\mathrm{K}$ admixture during multiple LTMC of Csl solution can be obtained from Fig. 2 .

The statistical treatment of the initial section $(N \leq 3)$ yields the approximation:

$$
\begin{gathered}
-\log c_{\mathrm{K}}=2.237( \pm 0.001)+ \\
+0.110( \pm 0.001) \cdot N, \quad \beta=0.7 .
\end{gathered}
$$

At $N>3$ the dependence is as follows:

$$
\begin{gathered}
-\log c_{\mathrm{K}}=2.08( \pm 0.07)+ \\
+0.226( \pm 0.001) \cdot N, \quad \beta=0.60 .
\end{gathered}
$$

That is, similarly to $\mathrm{Na}$ distribution, high common concentration of technogenic admixtures retards the purification of Csl the solution from potassium and this can be seen from $\beta$ values. As for $\alpha$ values, although they oscillate near $0.1(\log \alpha=-1$, this value agrees with [5]) it is seen from dependence 1 that this parameter decreases with the increase of $N$ and somewhat grows during the latest stages. This can be explained both by accuracy of analytical determination of $K$ and the fact that at extremely low concentration of an isomorphic admixture its distribution coefficient (and, hence, $\alpha$ ) grows since the amount of the admixture becomes comparable with the

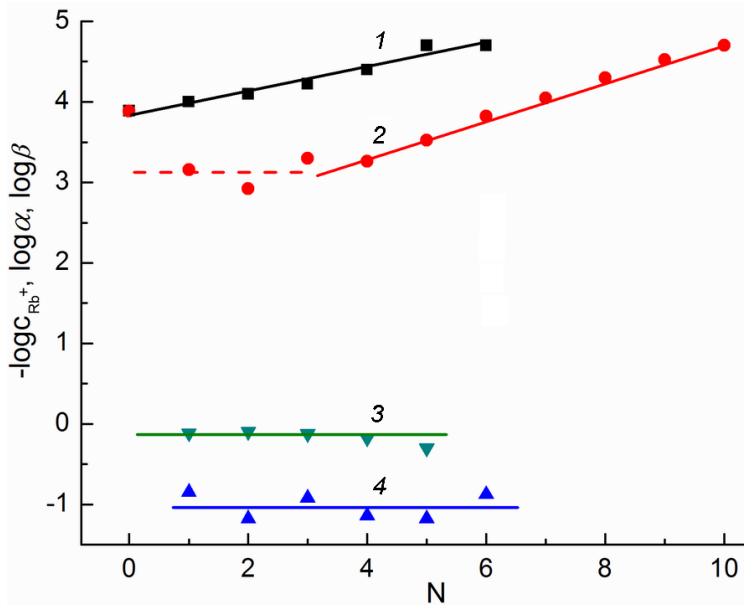

Fig. 3. The dependences of logarithm of $R b$ concentration $\left(-\log c_{\mathrm{Rb}}\right)$ in product (1), mother waters (2) and logarithms of thermodynamic $(\alpha)$ and effective $(\beta)$ purification coefficients on numbers of LTMC cycles $(N)$.

quantity of defects arising in the solid fraction. In this case the admixture is captured by the defects.

Besides potassium, $\mathrm{Rb}$ is also referred to very undesirable admixtures in cesium iodide since the natural rubidium contains $28.75 \%$ of ${ }^{87} \mathrm{Rb}\left(\beta-, \tau_{1 / 2}=4.8 \cdot 10^{10}\right.$ years) [9] and this admixture results in the increase of intrinsic radioactive background. The purification of Csl from this admixture is especially difficult taking into account that ionic radii of $\mathrm{Rb}^{+}$ and $\mathrm{Cs}^{+}$are close -0.152 and $0.167 \mathrm{~nm}$, respectively [10] and $\mathrm{Rb}$ is more isomorphic to $\mathrm{Cs}$ than $\mathrm{K}(0.138 \mathrm{~nm})$ or $\mathrm{Na}(0.102 \mathrm{~nm})$.

The experimental dependences of the concentrations and parameters describing the purification efficiency from the number of LTMC of Csl- $\mathrm{H}_{2} \mathrm{O}$ system are presented in Fig. 3.

It should be noted that, although the dependence of $\mathrm{Rb}$ concentration in mother waters vs. $N$ resembles the similar dependences for $\mathrm{K}$ and $\mathrm{Na}$, the dependence of $\mathrm{Rb}$ concentration in the product is practically linear:

$$
\begin{gathered}
-\log c_{\mathrm{Rb}}=3.84( \pm 0.05)+ \\
+0.148( \pm 0.01) \cdot N, \quad \beta=0.71,
\end{gathered}
$$

and authors of [11] estimated this parameter as $\approx 0.59$.

So, the effective coefficient of purification of $\mathrm{Csl}$ from $\mathrm{Rb}$ is closer to 1 than in cases of $\mathrm{K}$ and $\mathrm{Na}$ that makes the purification by LTMC more difficult. As for $\alpha$ value it oscillates around of $0.1(0.1 \div 0.15)$ that appreciably exceeds $k_{L}$ parameter obtained 
by Blank $(0.06 \pm 0.02)$ [5]. After $6^{\text {th }}$ LTMC the concentration of $\mathrm{Rb}$ becomes lower than the detection limit and this does not permit to perform correct estimations.

Distribution of $\mathrm{Cu}$ and $\mathrm{Tl}$.

The behavior of these admixtures is considered together due to two reasons. The first one consists in the fact that both cations $\left(\mathrm{Cu}^{+}\right.$and $\left.\mathrm{Tl}^{+}\right)$are precipitated by iodide ion as insoluble iodides, therefore, these admixtures should be accumulated in the solid phase during LTMC process. Other common feature is that the precipitated iodides can dissolve in solutions of alkali metal iodides forming iodide complexes: $\mathrm{Cul}_{2}^{-}$and up to $\mathrm{TII}_{4}{ }^{3-}$, respectively and the complexes of $\mathrm{Cu}$ are considerably stronger than $\mathrm{Tl}$ ones. The latter reason should lead to the accumulation of these admixtures in the mother waters.

$\mathrm{Cu}$ admixture is extremely harmful for the CsI-based scintillators since it affects the luminescent properties of the said materials. Authors of [12] showed that addition of $5 \cdot 10^{-6}$ wt. \% of Cul into the growth melt led to the formation of complex centers which distribution in the crystals is non-uniform due to non-isomorphism of $\mathrm{Cu}^{+}$and $\mathrm{Cs}^{+}$ $\mathrm{CCu}^{+}$was considered as isomorphic to $\mathrm{Na}^{+}$ [13]). The luminescence spectrum of Csl with $1 \cdot 10^{-6}$ wt. $\%$ of $\mathrm{Cu}$ contains an emission band with the maximum at $390 \mathrm{~nm}$. The rise of $\mathrm{Cu}^{+}$concentration to $2 \cdot 10^{-4} \mathrm{wt}$. $\%$ results in the shift of the maximum position to $620 \mathrm{~nm}$. Concentrations of $\mathrm{Cu}$ in Csl higher than $2 \cdot 10^{-5}$ wt. \% cause the decrease of the light yield by $30 \%$ [12].

As to the behavior of $\mathrm{Cu}^{+}$in the iodide solution, Cul is practically insoluble in water and the index of the solubility product $\left(p K_{s, \mathrm{Cu}}\right)$ :

$$
\mathrm{Cul} \downarrow \rightleftarrows \mathrm{Cu}^{+}+\mathrm{I}^{-}
$$

is equal to 11.96 [4]. Cul is dissolved in the excess of soluble iodides forming complexes:

$$
\mathrm{Cu}^{+}+2 \mathrm{I}^{-} \rightleftarrows\left[\mathrm{Cul}_{2}\right]^{-}, \log b_{2}=8.85,
$$

where $b_{i}$ the instability constant of the complex with $i$ ligands. Ditto, copper (I) can form dimers of $\mathrm{Cu}_{2}{ }^{2+}$ composition even in the diluted solutions and this trend is also observed even in molten salts [14]. So, the efficiency of $\mathrm{Cu}$ admixture displacement from Csl at LTMC is dependent on the concurrence of the precipitation and complexing processes. The dependences of LTMC pa-

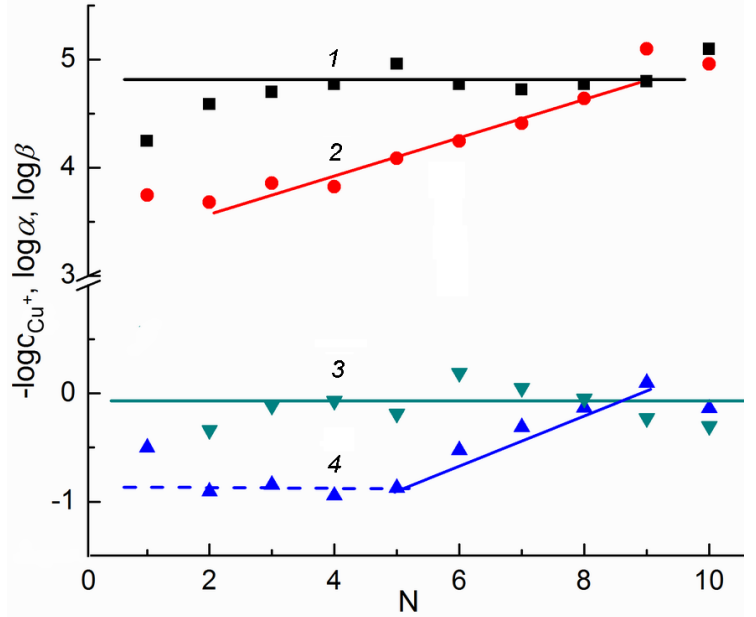

Fig. 4. The dependences of logarithm of $\mathrm{Cu}$ concentration $\left(-\log c_{\mathrm{Cu}}\right)$ in product (1), mother waters (2) and logarithms of thermodynamic $(\alpha)$ and effective $(\beta)$ purification coefficients on numbers of LTMC cycles $(N)$.

rameters vs. the number of cycles is presented in Fig. 4.

As is seen, there are two sections in the dependence of $\mathrm{Cu}$ concentration in the product. The first section is typical for an admixture displaced into the mother waters during the crystallization:

$$
\begin{gathered}
-\log c_{\mathrm{Cu}}=4.17( \pm 0.08)+ \\
+0.162( \pm 0.02) \cdot N, \quad \beta=0.69 .
\end{gathered}
$$

After the $5^{\text {th }}$ crystallization a plateau corresponding to $5 \cdot 10^{-5}$ wt. \% of $\mathrm{Cu}$ arises. It can be supposed that this is the limit of $\mathrm{Cu}$ removal from Csl at LTMC. As for the purification coefficient, $\beta$ values in the inclined section are close to 1 and $\alpha$ ones oscillate near 0.1 that agrees with [5].

So, the behavior of $\mathrm{Cu}$ resembles that of $\mathrm{Rb}$. It can be concluded that for $\mathrm{Cu}$ admixture complexing but not precipitation is the prevailing for LTMC process. A certain effect is caused by the non-isomorphism of $\mathrm{Cu}^{+}$and $\mathrm{Cs}^{+}$ions.

Although TIl is insoluble in water $\left(p K_{s}, \mathrm{TlI}=7.24\right)$, thallium admixture passes into the iodide wastes because of complexing of $\mathrm{Tll}_{i}(1-i)$ composition. These complexes are not so strong as those in the case of $\mathrm{Cu}$ $\left(\log b_{1}=1.41, \quad \log b_{2}=1.82, \quad \log b_{3}=2.0\right.$, $\log b_{4}=1.60$ [4]). This leads to the assuming that the distribution of TI during LTMC can differ from that of $\mathrm{Cu}$. Indeed, from Tables 1 and 2 it can be seen that $\mathrm{Tl}$ concentration in the mother waters during multiple LTMC remains practically constant whereas the 


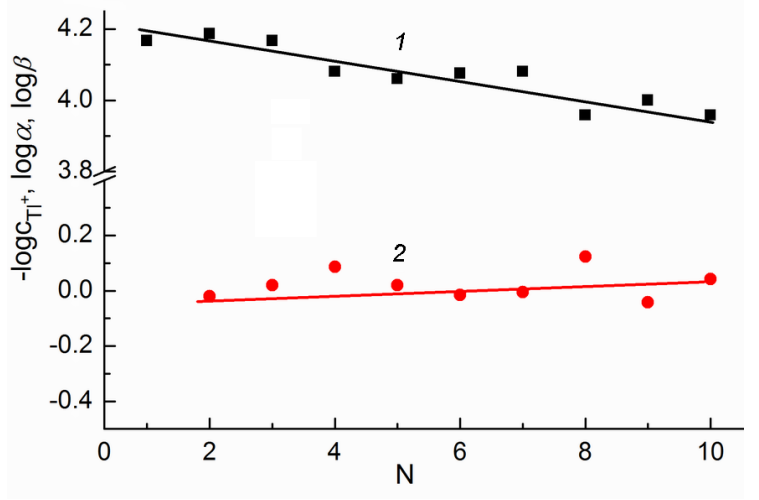

Fig. 5. The dependence of logarithm of $\mathrm{Tl}$ concentration $\left(-\log c_{\mathrm{T}}\right)$ in product $(1)$ and effective purification coefficient $(\beta)$ on numbers of LTMC cycles $(N)$.

amount of $\mathrm{Tl}$ in the crystallized fraction somewhat increases as it is demonstrated by the dependence 1 in Fig. 5 .

In contrast with the distribution of $\mathrm{Na}$, $\mathrm{K}, \mathrm{Rb}$ and $\mathrm{Cu}$ curve 1 for $\mathrm{Tl}$ (see Fig. 5) possesses negative slope meaning that the multiple LTMC leads to the enrichment of the solid phase with thallium and the corresponding dependence can be approximated as

$$
\begin{gathered}
-\log c_{\mathrm{TI}}=4.21( \pm 0.02)- \\
-0.025( \pm 0.003) \cdot N, \quad \beta=1.06
\end{gathered}
$$

So, the LTMC of the technogenic Csl solution did not lead to the displacement of $\mathrm{TI}$ from the crystallized fraction and $\mathrm{Tl}$ is accumulated in the product. The low solubility of TII in water, weak stability of iodide complexes of $\mathrm{Tl}$ and isomorphism of $\mathrm{Tl}^{+}$and $\mathrm{Cs}^{+}$ions facilitate the accumulation of $\mathrm{Tl}$ in the final product. It means that the crystallization methods do not permit to purify Csl solutions from $\mathrm{TI}$ up to the level necessary for the growth of pure Csl and the LTMC product could be used for the growth of Csl:TI single crystals.

To finish the consideration of the admixture distribution in Csl solutions during multiple LTMC let us stay on the distribution of sulfate ions. They are not referred to the isomorphic admixtures, therefore, their removal cannot be difficult. Ditto, the well-known technology of extra pure Csl production includes the chemical stage of sulfate separation using $\mathrm{Ba}(\mathrm{OH})_{2}$, namely:

$$
\mathrm{Ba}^{2+}+\mathrm{SO}_{4}^{2-} \rightarrow \mathrm{BaSO}_{4} \downarrow \text {. }
$$

Further, the excess of $\mathrm{Ba}(\mathrm{OH})_{2}$ is removed by $\mathrm{Cs}_{2} \mathrm{CO}_{3}$ excess and other alkaline

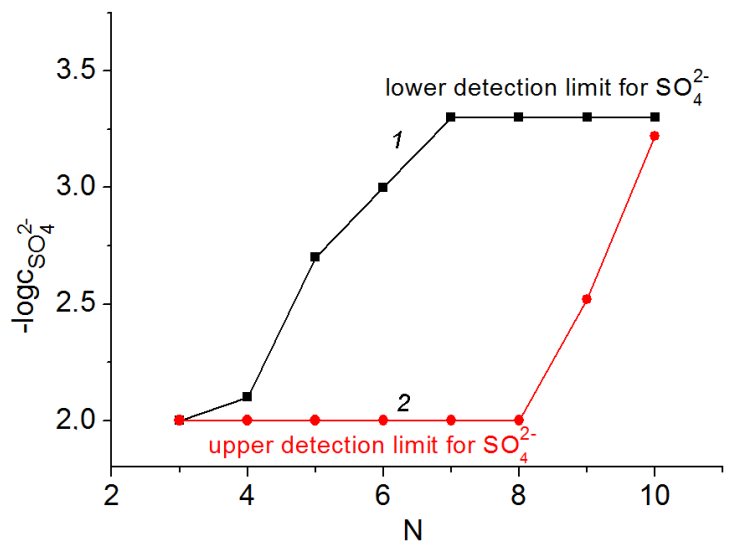

Fig. 6. The dependences of logarithm of $\mathrm{SO}_{4}{ }^{2-}$ concentration $\left(-\log c_{\mathrm{SO}_{4}}{ }^{2-}\right)$ in product (1) and mother waters (2) on numbers of LTMC cycles.

earth metal cations are also quantitatively removed.

The main source of sulfates in the liquid Csl wastes are the main water and products of commercial grease oil pyrolysis due to their possible entrance to the growth melt. The dependence of sulfate concentration in the product and mother waters are presented in Fig. 6. The data from the middle parts of the dependences can be approximated by the following equation:

$$
\begin{gathered}
-\log c_{\mathrm{SO}_{4}^{2-}}=0.62( \pm 0.3)+ \\
+0.39( \pm 0.05) \cdot N, \quad \beta=0.41
\end{gathered}
$$

Since the deviation of the value of $\beta$ from 1 is higher than for the other studied ions, sulfate ions can be removed from the technogenic Csl solution appreciably easier.

\section{Conclusions}

The very simple and suitable variation of the Csl wastes purification is proposed. It consists in the freezing of the wastes (3840 wt. \% solution of Csl) in 1.51 PET bottles in the freezing chamber cooled to $-10^{\circ} \mathrm{C}$ with the following removal of 3-5\% of mother waters. The way permits to purify Csl to the extra pure quality by 10-11 LTMC cycles.

Due to the considerable contamination of the technogenic wastes with sodium the removal of all the studied admixtures during 3 initial cycles is essentially slower than during the following crystallizations. The threshold position corresponds to $5 \cdot 10^{-2}$ wt. $\%$ of $\mathrm{Na}$ in the Csl solution.

Analysis of $\alpha$ and $\beta$ coefficient shows that $\alpha \neq \beta^{2}$ at multiple LTMC (the ideal cascade condition). Therefore, the product 
from the $n$ LTMC stage should be united with the mother waters from the $n+4$ stage of LTMC.

The purification coefficients for the main admixtures are estimated. For $\mathrm{Na} \beta$ value is $0.6-0.7$ for the initial Csl solution and decreases to $0.35-0.5$ for more pure solutions. The corresponding values for $\mathrm{K}$ are 0.75 and $0.5-0.55$, for $\mathrm{Rb} \beta$ changes is $0.65-0.75$ range. The value $\beta$ for $\mathrm{Cu}$ is closer to 1 than corresponding parameters for alkali metal cations (excluding $\mathrm{Rb}$ ) since Cul is insoluble in water and partially enters in the solid phase. Nevertheless, the strong complexing with iodide ions favors the displacement this admixture in the mother waters. For $\mathrm{Tl} \beta$ somewhat exceeds 1 that leads to the accumulation of this admixture in the product. This is caused by the isomorphism of $\mathrm{Tl}^{+}$to $\mathrm{Cs}^{+}$ions, the low solubility of TII in water and relatively weak complexing of $\mathrm{Tl}^{+}$with iodide ions. The displacement of sulfate ions at LTMC is the simplest among the considered admixtures since $\mathrm{SO}_{4}{ }^{2-}$ ions are non-isomorphic to the constituent ions of Csl.

Acknowledgement. The support of the physicochemical invesrigations was made by The National Academy of Sciences of Ukraine Program of Fundamental Research "New Functional Substances and Materials of Chemical Engineering", project No. 4-17 from 28.03.2017. The development of analytical methods of admixture determination was supported by Ministry of Education and Science of Ukraine, project of V.Karazin Kharkiv National University No. 16-15-16 (State Reg. No. 0116U000836).

\section{References}

1. http://www.crystran.co.uk/optical-materials/ caesium-iodide-cesium-iodide-csi.

2. M.E.Globus, B.V.Grinyov, Inorganic Scintillators. New and Traditional Materials, Akta, Kharkov (2000) [in Russian].

3. Properties of Inorganic Compounds. Handbook, ed. by A.I.Efimov et al., Khimiya, Leningrad (1983) [in Russian].

4. I.T.Goronovsky, Yu.P.Nazarenko, E.F.Nekryach, Short Handbook on Chemistry, Naukova Dumka, Kiev (1987) [in Russian].

5. A.B.Blank, Analysis of Pure Compounds with the Use of Crystallization Concentrating, Khimiya, Moscow (1986).

6. V.V.Banik, A.B.Blank, O.M.Smirnova, Abstr. $7^{\text {th }}$ All-Union Conf. Chemistry and Technology of Rare and Alkali Elements, Apatity (1988), p.120 [in Russian].

7. C.McCarthy, R.F.Cooper, S.H.Kirby et al., Amer. Mineralogist, 92, 1550 (2007).

8. Chemical Encyclopedy in 5 volumes, V.2, ed. by I.L.Knuniantz et al., Sovietskaya Entsyklopedia, Moscow (1990) [in Russian].

9. Chemical Encyclopedy in 5 volumes, V.4, ed. by N.S.Zefirov et al., Bolshaya Rossiyskaya Entsyklopedia, Moscow (1995) [in Russian].

10. http://abulafia.mt.ic.ac.uk/shannon/radius. php.

11. A.B.Blank, N.I.Shevtsov, "Monokristally i Tekhnika", All-Union Scientific and Research Institute for Single Crystals, Kharkov, Issue 14, 187 (1976) [in Russian].

12. A.N.Panova, R.Kh.Mustafina. "Monokristallty i Tekhnika", All-Union Scientific and Research Institute for Single Crystals, Kharkov, Issue 14, 110 (1976) [in Russian].

13. B.D.Stepin, I.G.Gorstein, G.Z.Blum et al., Methods of the Obtaining of Extra Pure Inorganic Substances, Khimiya, Leningrad (1969) [in Russian].

14. T.P.Boyarchuk, E.G.Khailova, V.L.Cherginets, Electrochim. Acta, 38, 1481 (1993). 